\title{
Women Candidates in Indonesia: Experience in Candidate Selection within Political Parties
}

\author{
Niken Larasati Kusuma Hapsari ${ }^{1}$, Sri Budi Eko Wardani ${ }^{2}$ \\ \{nkenkusuma@gmail.com ${ }^{1}$ \} \\ Universitas Indonesia, Indonesia ${ }^{1,2}$
}

\begin{abstract}
This research focuses on the experience of women legislative candidates in passing the selection process in political parties. This study explores the experience and challenges faced by women legislative candidates in the central level legislative and regency/city level legislative council for the 2019-2024 period. Women legislative candidates are drawn from three parties, namely Golongan Karya, Nasional Demokrat dan Partai Keadilan Sejahtera. Data collection was carried out through the study of political party AD / ART documents, direct discussions, and in-depth interviews. Research results show that regulation in political parties has not fully favored female candidates. The high authority of party elites in the selection process has an impact on the number of female candidates who are nominated based on their proximity to the party elite.
\end{abstract}

Keywords: Women in parliament, candidate selection, women and political parties, women's political agenda, affirmative action.

\section{Introduction}

The patriarchal culture which rooted in political parties led to the birth of the notion that politics is a masculine realm and identical to men. This assumption resulted a lack of support from political parties on women's representation. Even though the $30 \%$ affirmative action quota policy for women's representation has been implemented, many political parties still consider women's representation as a formality. This can be seen from the fact that political parties only recruit women's legislative candidates just before the general election. Women candidates are recruited only to fulfill the minimum quota.

In carrying out the recruitment process, political parties implement the same policies to both women and male candidates. There is no specific recruitment policy intended for women candidates. This is because the recruitment policy is the authority of political parties. In addition, the affirmative action policy embodied in UU No. 31 of 2002 concerning Political Parties, UU No. 2 of 2008 concerning Political Parties, UU No. 12 of 2003 concerning Elections, UU No.10 of 2008 concerning Election of Members of the People's Legislative Assembly, Regional People's Legislative Assembly and UU No.7 years 2017 article 173 paragraph 2 only regulates the number of nominations for women candidates submitted by the party and serial numbers. Therefore, the recruitment aspect carried out by the party is not affected by the affirmative action policy.

The implementation of candidate selection policy with a common pattern between women and male candidates will present the candidate selection process who are gender-biased and 
produce an unbalanced number of women and male candidates. According to Notosusanto[1], in the selection process, the party tends to recruit and select candidates who have close relations with the party elites. Of course, this will be a disadvantage to most women candidates who have minimal political experience and no closeness to the party elite. This situation can be seen by the presence of women candidates who are removed from the list of candidates because there are men who are party leaders or have economic power who prefer the position held by the women candidates[2]. This situation is very unfortunate because party is the gateway for women entering the political world and the process of selecting candidates is a general description of a political party in placing women in their respective political parties[3]. The low level of women candidates shows an imbalance in political representation that is not in accordance with the nature of the functional representation model[4]. One of them is influenced by the recruitment process faced by women candidates. Inequality between the representation of women and men will also result in women's interests not being accommodated and the emergence of less gendersensitive policies.

Then it can be agreed that the process of selecting candidates is carried out by political parties still do not have a pattern that gives favor for women candidates. The recruitment process in political parties is still seen as this "double-edged sword" because on the one hand, and it is clear that nomination must go through the party, coupled with the affirmative policy, the party must nominate women. However, on the other hand, women candidates must be very observant and sensitive in playing the space available internally in their parties, especially when they are dealing with party structures in their constituencies[5]. As a matter of fact, the process of selecting candidates in political parties has a significant impact on politics in general, such as the distribution of power, elected types of legislative members, the behavior of elected legislative members and also the number of nominations[6]. This recruitment process will affect the experience of women and male candidates. Moreover, this candidate selection pattern will cause differences in selection experience among women candidates. This difference in experience comes from various party regulations, backgrounds, and social networks owned by women candidates.

In 2019 election $3.200(40.07 \%)$ women ran for parliament. The percentage of this nomination is the highest compared to the previous election. In the 2009 election, only 1.589 $(31.8 \%)$ women candidates ran for parliament. There was an increase in the 2014 election, but the increase was not significant, only around 2.061 (37.9\%)[7]. With the highest level of the nomination of women candidates, it is interesting to examine the 2019 general election. Although, the nomination of women candidate's percentage still lower when compared to the level of the nomination of male candidates, it important to find out how different candidate selection process is in each party that affects the nomination. Therefore, to find out how the selection process experienced by women candidates will be presented the experience of three women candidates with the background of three different political parties. The three women candidates were Nurul Aisaturida who came from the Golongan Karya (Golkar) Party, Reztya Ridwan from the Partai Keadilan Sejahtera (PKS) and Silkania Swarizona from the Nasdem Party. The selection of these three sources is based on the existence of different professions, family backgrounds, and political parties that buckler them. The three political parties chosen to have different typologies. Golkar Party and Nasdem Party are mass parties, while PKS is a cadre party. This difference in typology will then present a variety of candidate selection patterns. The only similarity they have is that they were only nominated for the first time and the selection process in political parties.

There are several studies that have discussed the process of recruiting and selecting candidates in political parties. However, few studies have looked at the candidate selection 
process from the perspective of selected women candidates. Ani Soetjipto and Shelly Adelina[8] in "Partai Politik dan Strategi Gender Separuh Hati: Pelajaran dari Pengalaman Tiga Partai Pemenang Pemilu 2009", found that political parties in Indonesia did not have specific provisions regarding gender policies and they also did not have a strategy in improving gender justice. Second, the efforts made by the three political parties were only to bring women focal points (the main focus on women) embodied in women's departments in each party but did not provide an understanding of the function of the women's department, namely women's empowerment in the community.

The study which specifically discusses the experience of women candidates in political parties only emphasizes one aspect of the discussion of the candidate recruitment or selection processes, such as Soetjipto, Wardani, Perdana, Panjaitan and Ichwanuddin[5] which emphasizes the strategy experience of five women candidates. Success in general elections. In this study, it was found that women who come forward as candidates, on average had passed a certain phase of activity in the non-political world (social and economic) so that they could be used by the party as vote-getters. Also, one of the factors at the starting point of their involvement was because politics was not a stranger in their family environment, they grew up in a family environment that had relatively intense political interactions. Audrey Vandaleene[9] examines candidate selection in Belgium by looking at the characteristics of candidate selection actors in terms of complexity and institutionalization of candidate selection. In her research, he found that strict regulations and actors given authority in the candidate selection process had a significant impact in giving candidates women positions that promised to win. Meanwhile, Soetjipto[2] argues that the background of women candidates falls into politics other than family factors, also because they actually come from organizations traditionally affiliated with certain parties. However, in her research Ani Soetjipto did not see the entire candidate selection process, this study only looked at how women candidates were removed from the nomination by male candidates who had strategic positions within the party so that the experience of the women candidates faced the overall candidate selection process.

In this study, author uses the concept of candidate selection Richard E. Matland[10], which classifies the candidate selection process into three stages, namely self-selection, party selection, and voter selection. Author limits this study only in two stages of selection, self-selection, and selection by political parties. This is done so that this study can be more focused on the experiences experienced by women candidates. The author believes that the experience of selecting candidates for each women candidate will certainly be different and is a valid experience because of the different backgrounds and social networks that each candidate has.

This study has several contributions, theoretically and practically. Theoretically, this study is expected to add to the discussion about candidate selection and show how the experience of women candidates in the selection process in political parties. Practically, this research is expected to be a reference for political parties to see which candidate selection method is best to help efforts to increase the nomination of women candidates in election contestations. In addition, this research can also be a guide for women who intend to run for women candidates in the next election. This study aims to explain the experience of candidate selection experienced by women candidates in political parties in the 2019 general election. To achieve this goal, the researcher will examine the experiences of women candidates starting from the background, social networks, and political parties of women candidates. The researcher will focus on how much influence these factors have on the candidate selection experience. Before that, the research methodology used will be discussed first.

\section{Research Methods}


The research method used in this study is qualitative. Qualitative methods are used because this study aims to understand and explore problems and phenomena originating from humans [11]. This method is suitable for use in researching the experiences of women candidates. Meanwhile, the approach used is an ethnographic approach. The ethnographic approach was chosen so as to allow for more in-depth discussions with the informants relating to the information they provided, or the interpretations of the results obtained. The determination of research informants was determined intentionally (purposive) departing from the value aspects related to the informant and based on the nature and purpose of the study. In this study, the values used as a reference by researchers are differences in regulation and selection mechanisms in political parties as well as differences in social networks. The social network in question includes kinship social networks and professional social networks that will influence the experience of selecting candidates from women candidates.

There are two data collection techniques used in this study. First, primary data collection techniques through in-depth interview methods, this technique is used to informants: Nurul Aisaturida, Silkania Swarizona, and Reztya Ridwan. In-depth interviews are conducted using semi-structured and open types of questions so that researchers can get more in-depth information. Second, in completing the primary data, the researcher uses literature studies to strengthen the arguments that were built in this study.

\section{Result and Conclusion}

\subsection{Experience of Candidate Women Legislative Members Selection}

For women, the decision to run for legislative candidates is not a simple decision. Before entering the nominating, process women must convince themselves that they can compete with male candidates, they must also consider the strategies that will be used to get through the selection process. According to Richard E. Matland [8], when a woman nominates herself to become a member of parliament, she must go through three stages. First, women must select themselves for candidacy. Second, women are selected as candidates by the party and third, women are selected by voters.

To examine the experience of women legislative candidates, this study will look at two stages of selection, that is the stage of self-selection and the stage of political party selection. The stages of self-selection are used to describe the internal dynamics of women which consist of motivation in nominating themselves, the background and social networks needed by women candidates. Meanwhile, the selection stage by political parties will be seen through a recruitment system that applies to political parties and actors that influence the selection process.

In the self-selection stage, a woman is usually influenced by two factors, namely personal ambition and the opportunity to run for election. Women's assessment of their opportunities and their desire to run for office will be influenced by the amount of opportunity to nominate themselves, how friendly the political environment will be to support his candidacy, and the estimated resources that can be used to help him in running for office[10]. This section will look at the background of the three women candidates and what personal motivation they have until they finally get the chance to run for office.

Nurul Aisaturida is a woman candidate that runs from the Golkar Party. As a women legislative candidate, she has a concern for women's issues in her area. This concern arose when she promised as staff of the Corporate Social Responsibility (CSR) of a mining company in 
Kalimantan. She saw so many women who were helpless and living in the poverty line. The opportunity to run for office arose because she came from a family active in the Golkar Party. In her nomination, Nurul was offered directly by the party elite in her area. Not much different from Nurul Aisaturida, Reztya Ridwan is a women legislative candidate from PKS. She also has the motivation to run in the legislative elections because she has a concern for the high level of women in Sukabumi who women labor is abroad. Reztya had the opportunity to run because she had family that active in the political party. Her father was a cadre since PKS was in the form of the Justice Party (PK), while her mother and uncle, Alit Gunawan, had first entered politics by participating in the legislative contest of Sukabumi City DPRD in 2004, 2009 and 2014. This woman who were studying Master of Science Politics at the University of Indonesia's Faculty of Social and Political Sciences (FISIP) has been a party cadre for quite a long time and received an offer to become a legislative candidate directly from the Chairman of the PKS DPD, Dr. Asep Tajul, through her father.

In contrast to Nurul and Reztya, Silkania Swarizona, who is a woman candidate from the Nasdem party, does not come from a family active in political parties. Silkania is a singer and presenter. Knowledge about politics she got when he was studied in Political Science at the Faculty of Social and Political Sciences, Airlangga University. In 2018, this woman who was completing her Master of Political Science study at the University of Indonesia counted four years as an active cadre of the Nasdem party. As an active cadre, the offer to become a legislative candidate in the 2019 Election came to her through one of the political elites in Nasdem. Although she was hesitant because she did not have much experience in contestation, she finally accepted the offer with her main motivation for women's empowerment and develope creative industry in Sidoarjo.

The explanation above shows that the background and reasons for women candidates joining as legislative candidates are quite diverse. However, there are similarities between the three candidates, that is a concern for women's issues in their area. Also, in their candidacy, the three candidates received direct offers from elite political parties to become legislative candidates. This shows that the recruitment process in political parties towards women candidates has many forms, not only through formal processes but also informal processes. The nominating process that takes place informally will make the selection system in political parties exclusive and only benefit women candidates who have close ties with the party elite.

The narrative of the three candidates above shows that informal recruitment is still a lot going on in the process of nominating women candidates. Although the government has regulated the recruitment provisions listed in UU No. 2 of 2008 and PKPU in 2013 about the minimum quota of $30 \%$ women in the political party structure and a list of legislative candidates, often this nomination process is still dominated by the interests of the party elite[12]. This is because the recruitment process, especially the selection of candidates is still unregulated by the government. The candidate selection by political parties, Gallagher and Marsh [13] categorized the candidate selection as 'secret garden of politics' process. It is called a "secret garden of politics because the selection process of candidates in political parties is a crucial activity in political parties, but because of the internal power struggles it entails, the selection process of candidates is categorized as internal party affairs[14].

In the selection process, even though the three candidates had close ties to the party elite, it did not mean that the nomination process they went through was without problems. For Nurul, obstacles were felt when determining the level of nomination. At first, she intended to run at the DPRD district or provincial level so that her chances of winning were greater. However, it turned out that this desire had to be dashed because the position in the district/city and province was full. If at that time she forced to enter the district/city or provincial DPRD level, the 
consequence was that she had to deal with party leaders in the area. Therefore, she finally ran for office at the DPR RI/ central level. Although, when she nominated herself at the central level, she had to compete with the incumbent legislators and party administrators in the political party central board.

Meanwhile, the obstacle experienced by Reztya was the doubt that she felt because she was a new cadre and had not had much experience. Also, Reztya was given position number nine at ballot because she was a new cadre. Almost the same as Nurul and Reztya, the obstacles experienced by Silkania also occur when she chooses number in the ballot. When she negotiated with the party management in her district to get a good position in the ballot, she got rejected. That's because the number one position had been occupied by the chairman of Bapillu and the number two had been occupied by one of the heads of the branch boards. So finally, she got number three in the list of permanent candidates (DCT). From the explanation above, it can be seen that the obstacles experienced by the three women candidates are in the process of serial numbering, the party regulations that have regulated these stages do not function properly. Giving the serial number is still the permanent authority of the party elite, so most women candidates do not get the top number. Based on data compiled by Cakrawikara, as many as $44 \%$ of elected women candidates are candidates placed in number one, and as many as $29 \%$ of candidates in number two are followed by $20 \%$ of candidate numbers three. The practice of giving this serial number shows that political parties still see women's representation as an administrative prerequisite and have not been serious in encouraging women's electability.

The process of self-selection and selection by the political parties are connected. In going through the different party selection processes, women candidates still have some similarities. First, the process of nominating women candidates still runs through informal channels based on proximity to party elites. Even though political parties already have standard regulations, in practice the nomination process is still dominated by the appointment of party elites. Second, the regulation of candidate selection in political parties has not favored women candidates. The same regulation of candidate selection between women and male candidates results in genderbiased selection practices and disserve women. This can be seen from the many women candidates who were excluded because they lost to male candidates who had money or positions. Third, the process of giving serial numbers is still the main obstacle when women go through the candidate selection process. Regulations regarding the application of zipper systems aimed at increasing women's electability have not run optimally. The battle for obtaining the top sequence number is still difficult for women. Because women candidate still losing to male candidates who have important positions in political parties, also the notion that women are only a compliment in nomination has resulted in the party not putting women candidates in strategic positions.

\section{Conclusion}

This study found that regulation in political parties has not fully favored female candidates. Regulation of candidate selection in political parties is often not implemented. The high authority of party elites in the selection process has an impact on the number of female candidates who are nominated based on their proximity to the party elite. 
Most female candidates are only considered as complementary or as vote-getters, so they are not given a strategic position in the ballot. This problem is also related to the number of women candidates who are marginalized and get the bottom number because they are inferior to male candidates who have money or positions.

\section{References}

[1] S. Notosusanto, "Menjalin Kerjasama antara Masyarakat Madani dan LembagaLembaga Politik," Int. IDEA, 2008.

[2] A. Soetjipto, Politik Perempuan Bukan Gerhana. Jakarta: Kompas Gramedia, 2005.

[3] M. Tremblay, "Women and Legislative Representation: Electoral System, Political Parties and Sex Quotas.," Palgrave Macmillan, p. 2, 2012.

[4] H. F. Pitkin, The Concept of Representation. Berkeley: University of California Press., 1967.

[5] A. Soetjipto, A. Perdana, Y. Panjaitan, W. Ichwanuddin, and S. B. Eko Wardani, Menyapu Dapur Kotor Refleksi Perempuan dan Politik Era Reformasi. Jakarta: Parentesis Publisher, 2010.

[6] R. Y. Hazan, Candidate Selection. London: Sage Publication, 2009.

[7] Puskapol UI, “Analisis Perolehan Kursi DPR RI Pemilu 2019,” 2019.

[8] Ani Soetjipto, Partai Politik dan Strategi Gender Separuh Hati: Pelajaran dari Pengalaman Tiga Partai Pemenang Pemilu 2009. 2012.

[9] A. Vandeleene, "GENDER QUOTAS AND 'WOMEN-FRIENDLY' CANDIDATE SELECTION: EVIDENCE FROM BELGIUM,” Representation, vol. 50, no. 3, pp. 337-349, Jul. 2014.

[10] R. E. Matland, "Meningkatkan Partispasi Politik Perempuan: Rekrutmen Legislatif dan Sistem Pemilihan," IDEA, 2002.

[11] J. Creswell, Research Design Pendekatan Kualitatif, Kuantitatif dan Mixed. Yogyakarta: Pustaka Pelajar, 2012.

[12] A. M. Pratiwi, "Kebijakan, Praktik dan Politik Keterwakilan Perempuan dalam Partai Politik: Studi Kasus Aleg Perempuan DPRD Kabupaten/Kota Periode 2014-2019,” J. Peremp., vol. 24, no. Perempuan dan Demokrasi, 2019.

[13] M. Gallagher and M. Marsh, Candidate Selection in Comparative Perspective: The Secret Garden of Politics. London: Sage Publication, 1988.

[14] M. . Nelson, "Analyzing Provincial Political Structures in Thailand: Phuak, Trakun, and Hua Khanaen," SEARC Work. Pap. Ser. (Hong Kong Southeast Asia Res. Cent. City Univ. Hong kong), 2005. 